IRA-International Journal of Management \& Social Sciences

ISSN 2455-2267; Vol.05, Issue 03 (2016)

Pg. no. 443-450

Institute of Research Advances

http://research-advances.org/index.php/RAJMSS

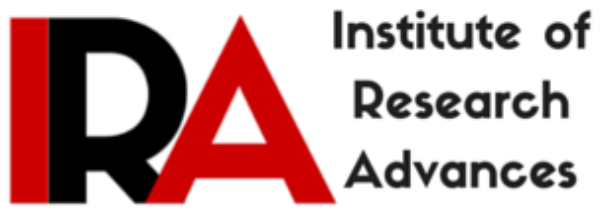

\title{
India's Trade Potential and Prospects with Bhutan
}

Sadhna

Research Scholar,

Department of Evening Studies,

Panjab University, Chandigarh-160014, India.

Type of Review: Peer Reviewed.

DOI: http://dx.doi.org/10.21013/jmss.v5.n3.p7

How to cite this paper:

Sadhna (2016). India's Trade Potential and Prospects with Bhutan. IRA-International

Journal of Management \& Social Sciences (ISSN 2455-2267), 5(3), 443-450. doi:http://dx.doi.org/10.21013/jmss.v5.n3.p7

(C) Institute of Research Advances

(c)) EY-NO

This work is licensed under a Creative Commons Attribution-Non Commercial 4.0 International License subject to proper citation to the publication source of the work.

Disclaimer: The scholarly papers as reviewed and published by the Institute of Research Advances (IRA) are the views and opinions of their respective authors and are not the views or opinions of the IRA. The IRA disclaims of any harm or loss caused due to the published content to any party. 


\begin{abstract}
Since mid 1990s, India is actively engaging in bilateral and regional negotiations with various countries and blocs to boost trade and level of integration. It has signed numerous agreements and become member. In South Asia region, India has close and trouble free relations only with landlocked kingdom i.e. Bhutan since 1949 under Treaty of Peace and Friendship. This treaty helped to enhance their integration i.e. free trade agreement (FTA) in goods signed between them in 2006. It is in this context, the present study applies revealed comparative advantage (RCA) and trade intensity index (TII) to explore India's trade potential and prospects with Bhutan that will tell us either India has trade possibility with Bhutan or not. The major findings of the study showed that India has become the largest trading partner of Bhutan. India has strong and sustainable trade potential with Bhutan. Even India has no specialisation in the export of any product to Bhutan but still exports continued to increase at walking rate. Overall, India has strong trade prospects with Bhutan.
\end{abstract}

Keywords: India; Bhutan; Trade; Potential; Prospects

\title{
Introduction
}

Under the wave of regionalism 1 slow and failure of trade negotiations at multilateral level (Bhagwati, 1993; Krugman, 1993; Ethier, 1998), India ${ }^{2}$ like other developing countries has negotiated and signed various bilateral and regional trade agreements with great enthusiasm as shown in Table- $1 .{ }^{3}$ Among South Asian countries, India has only smooth and free relation with the Himalayan Kingdom of Bhutan ${ }^{4}$ (Devi, 1989). Bhutan also remains an example of bilateralism in the India's neighbourhood. ${ }^{5}$ No doubt, both countries are diverse in size, economic and social development, geography, political system, language and culture (Table-2), but there relation continued to improve and became closer. India has become the largest trading as well as development partner of Bhutan. India from time to time has supported Bhutan's developmental effort. ${ }^{6}$ Bilateral trade continued to increase at increasing rate as shown in table-3. India's exports to Bhutan increased to US\$2,00,366 thousand (2014) from US\$2,154.84 thousand in 1990. Similarly imports also increased to US\$ 1,44,346 thousand (2014) from US\$ 798.02 thousand in 1990 (table-3). Major imports of India from Bhutan are iron and steel, mineral fuels, inorganic chemicals, plastic and articles, beverages, cooper and wood articles. Similarly India's major exports to Bhutan are mineral fuels, nuclear reactors, vehicles, articles of iron and steel, electrical machinery and equipments, salt, sulphur, rubber and plastic articles. ${ }^{7}$

\section{Objectives of the Study}

1. To briefly explain India's relation with Bhutan,

2. To identify the comparative advantage/trade specialisation in the exports and imports for commodities, at 2-digit level mentioned in Standard International Trade Classification (SITC) revision-2, in order to explore potential areas for further cooperation and

3. To explore intensity of India's trade with Bhutan.

\footnotetext{
${ }^{1}$ Regionalism' in international relations refers to the integration of a number of states, located in a certain geographical region, based on their common identity or the sense of collective actions. The process of integration often expressed through institutional mechanisms. The main objectives behind this integration are to facilitate trade among member countries by reducing tariff and non-tariff barriers on selected products, promote economic cooperation, build a sense of security and enhance the level of integration.

http://www.stanford.edu/class/polisci243b/readings/v0002093.pdfhttp://www.garnet-eu.org/pdf/Fawcett1.pdf

http://ageconsearch.umn.edu/bitstream/16137/1/mt040065.pdf

${ }^{2} 7^{\text {th }}$ largest ${ }^{2}$ and the second most populous $(1,267,401,849)$ country after China $(1,364,270,000)$ in the world

${ }^{3} \mathrm{http}: / /$ rtais.wto.org/UI/PublicAllRTAList.aspx

${ }^{4}$ Bhutan is located between China and India, two heavy-weight players in the international arena

${ }^{5}$ www.bhutanstudies.org.bt/publicationsfiles/jbs/jbs_vol.11/vii_6.pdf

${ }^{6}$ www.bhutanstudies.org.bt/publicationsfiles/jbs/jbs_vol.11/vii_6.pdf

${ }^{7}$ International Trade centre (ITC), Geneva
} 


\section{India's Relation with Bhutan: Historical Prospective}

India's relations with Bhutan are dated back to 747 A.D., when the great Indian saint Padmasambhava (known in Bhutan as Guru Rinpoche and sometimes referred to as the Second Buddha)came to Bhutan and introduced Buddhism. Besides cultural and religious heritage, both countries developed other areas of cooperation during the period of British India Company. In 1910, British signed Treaty of Punakha with Bhutan that laid the foundation stone of its relation in the subsequent years. Through this treaty, Bhutan gave full authority to India to control and regulate its foreign affairs and defence. ${ }^{8}$

After India's independence, standstill agreements with Sikkim, Nepal and Tibet were signed in order to continue existing relations; until the new agreements are signed. It was followed by Nehru's invitation to Bhutanese delegation to participate in the first international Asian Relations Conference in 1947. Following this, Maharaja Jigme Wangchuk sent delegates to India to participate and negotiate a fresh treaty.Indian government welcomed them and assured the government of Bhutan that it would respect Bhutan's autonomy if it wanted to maintain the same relations with independent India as under British rule. Maharaja Jigme Wangchuk continued negations with the government of India. As a result India and Bhutan signed 'Treaty of Peace and Friendship' in Darjeeling on 8 August 1949 which replaced the earlier treaty of 1910 between the British Indian government and Bhutan. This treaty was signed by the representatives of the Government of India and Government of his highness the Druk Gyalpo (the King of Bhutan). ${ }^{9}$

Based on this background, Indo-Bhutan relations began to take on concrete form. Formal trade relations between Bhutan and India were established in 1968 with the appointment of a resident representative of India in Thimbu (Bhutan). Before this our relation with Bhutan was looked after by our political officer in Sikkim. ${ }^{10}$ The Treaty of Friendship and Cooperation 1949 expired in 2006 and renewed for a period of 10 years by Pranab Mukherjee, the then India's Minister of External Affairs and Jigme Khesar Namgyal Wangchunck, the then crown prince and king of Bhutan's during his visit to India on 8 February 2007. The regular visits of ministers between countries and exchange of views enhanced relation. The share of this today unique relation goes to the efforts of Indian Prime Minister Pandit Jawharlal Nehru and the $3^{\text {rd }}$ Kind of Bhutan Jigme Dorji Wangchuck (Malik and Sheikh, 2016)

\section{Research Methodology}

In order to find India's trade potential and prospects with Bhutan, the analytical tools used for the study are as follows:

1) Revealed Comparative Advantage (RCA) (Balassa, 1965) for exports and imports by India to Bhutan identify trade specialisation. The index of revealed comparative advantage has a simple interpretation. Value greater than 1 for RCAX/RCAM indicates a comparative advantage while less than 1 for RCAX/RCAM indicates comparative disadvantage for the economy in the export/import of given product.

2) Trade Intensity Index (TII) (Drysadale and Garnaut, 1982) for exports, imports, and total trade between India and regional trade bloc members to see trade potential. A unitary value i.e., TII=1, shows that there is no difference in importance to a nation $\mathrm{i}$ in supplying imports to nation $\mathrm{j}$. Trade intensity index with a value greater than one (TII>1) indicates higher bilateral trade than can be expected on the basis of their share in world trade. When the value of intensity is high between two countries, it shows that both have more potential of trade with each other.

\footnotetext{
${ }^{8}$ http://www.bhutanstudies.org.bt/publicationFiles/JBS/JBS_Vol11/v11-6.pdf

${ }^{9} \mathrm{http}: / /$ www.globalindiafoundation.org/Bhutan\%20History.pdf

${ }^{10} \mathrm{http} / / / 164.100 .47 .192 /$ loksabha/writereaddata/Library/Reference\%20Notes/India's_Border_Management.pdf
} 


\section{Results of the Study}
a. Results of Revealed Comparative Advantage for Exports (RCAX)
Table-4 Products with Value of RCA Greater than 1 for Exports to Bhutan from India

\begin{tabular}{|c|c|l|}
\hline $\begin{array}{c}\text { Serial } \\
\text { No }\end{array}$ & $\begin{array}{c}\text { Product } \\
\text { Code }^{\mathbf{1 1}}\end{array}$ & \multicolumn{1}{c|}{ RCA Characteristics } \\
\hline 1 & 22 & $\begin{array}{l}\text { India was having RCA in this product till 2004, but thereafter RCA tended to } \\
\text { decline. India today has lost RCA in this product }\end{array}$ \\
\hline
\end{tabular}

* This table-4 is contrasted after seen annexure-2. Products whose RCA is greater than 1 and near to 1 i.e. 0.99 are taken as trade specialisation in that particular commodity. After seen annxure-2, it is found that India has no trade specialization in the exports of any product to Bhutan as shown in Table-4.

* Product with code 22 maintained its specialisation only for a couple of years but could not keep it (See annxure-2).

\section{b. Results of Revealed Comparative Advantage for Imports (RCAM)}

Table-5 Products with Value of RCA Greater than 1 for Imports by India from Bhutan

\begin{tabular}{|c|c|c|}
\hline $\begin{array}{l}\text { Serial } \\
\text { No }\end{array}$ & $\begin{array}{c}\text { Product } \\
\text { Code }^{13}\end{array}$ & RCA Characteristics ${ }^{14}$ \\
\hline 1 & 11 & The product had RCA from 2003 to 2004 but could not maintain it thereafter. \\
\hline 2 & 15 & Except 2007, India has no RCA in this product \\
\hline 3 & 20 & $\begin{array}{l}\text { India was not having RCA in this product since } 2001 \text {, but has started having RCA } \\
\text { only after } 2002 \text {. The trend of RCA tended to decline and lost trade specialization } \\
\text { in this product. India again showed RCA after long time }\end{array}$ \\
\hline 4 & 22 & $\begin{array}{l}\text { India had sustainable and strong RCA in product from } 2003 \text { to } 2009 \text {. However, } \\
\text { the product lost RCA }\end{array}$ \\
\hline 5 & 28 & $\begin{array}{l}\text { The product had RCA for a couple of years but could not keep it after } 2004 \text {. } \\
\text { However, India again showed RCA in this product in } 2008 \text { and continued to } \\
\text { sustain }\end{array}$ \\
\hline 6 & 37 & Except 2005 \& 2007, India has no RCA in this product since 2001 \\
\hline 7 & 54 & $\begin{array}{l}\text { There is not having RCA in this product except for } 2005 \text {. RCA was greater than } \\
\text { only in } 2005 \text {. }\end{array}$ \\
\hline 8 & 72 & $\begin{array}{l}\text { India was no having RCA in this product since 2001, but has started having RCA } \\
\text { only after } 2008\end{array}$ \\
\hline 9 & 74 & The product has sustainable and strong RCA with rising trend since 2003 \\
\hline
\end{tabular}

* As seen from table-5, products with code $11,22,28 \& 37$ were having comparative advantage $(\mathrm{RCA}>1)$ for a couple of years but lost it thereafter and could not regain its specialisation. This is said after seen annxure-3.

\footnotetext{
${ }^{11}$ See Annexure-1

${ }^{12}$ See Annexure-2

${ }^{13}$ See Annexur-1

${ }^{14}$ See Annexure-3
} 
* India has sustainable and strong RCA in product with code 74 i.e. RCA>1 (Annxure-3). The trend of RCA is on increasing mode.

* India has no trade specialization in products with code 15 \& 54 since 2001.

* As from above table-5, products with code 20 \& 72 had no RCA since 2001 but started to gain after a couple of years. Product with code 20 showed its specialization on this product after 2002. Similarly, product with code72 has developed RCA after 2008 (Annxure-3).

\section{c. Results of Trade Intensity Index (TII)}

Table-6 Intensity of Trade Index of India with Bhutan

\begin{tabular}{|c|c|c|c|}
\hline Year & $\begin{array}{c}\text { TII for Total Trade } \\
\text { between India and } \\
\text { Bhutan }\end{array}$ & $\begin{array}{c}\text { TII for Exports } \\
\text { by India to } \\
\text { Bhutan }\end{array}$ & $\begin{array}{l}\text { TII for Imports by } \\
\text { India from Bhutan }\end{array}$ \\
\hline 1990 & 20.5447 & NA & $\mathrm{NA}$ \\
\hline 1991 & 2.6596 & NA & NA \\
\hline 1992 & 21.9590 & NA & NA \\
\hline 1993 & 43.8901 & 14.5272 & 53.1088 \\
\hline 1994 & 152.3286 & 18.1914 & 545.179 \\
\hline 1995 & 244.6013 & NA & NA \\
\hline 1996 & 382.3565 & $\mathrm{NA}$ & NA \\
\hline 1997 & 92.3914 & NA & $\mathrm{NA}$ \\
\hline 1998 & 82.2428 & 11.7318 & 110.8996 \\
\hline 1999 & 114.3032 & 6.5518 & 305.5251 \\
\hline 2000 & 60.8825 & NA & NA \\
\hline 2001 & 101.6071 & NA & NA \\
\hline 2002 & 157.9233 & NA & NA \\
\hline 2003 & 298.5599 & NA & NA \\
\hline 2004 & 54.3545 & NA & NA \\
\hline 2005 & 190.8773 & 101.6222 & 251.8796 \\
\hline 2006 & 128.6445 & 47.8151 & 91.4348 \\
\hline 2007 & 127.8312 & 50.0601 & 112.5153 \\
\hline 2008 & 193.8613 & 64.9779 & 342.9872 \\
\hline 2009 & 76.3301 & 63.2188 & 223.3078 \\
\hline 2010 & 74.2573 & 49.6426 & 120.2377 \\
\hline 2011 & 101.9572 & 43.4747 & 79.4247 \\
\hline 2012 & NA & 48.0203 & 199.9914 \\
\hline 2013 & 89.6755 & NA & NA \\
\hline 2014 & 158.1425 & NA & $\mathrm{NA}$ \\
\hline
\end{tabular}

The above Table- 6 shows that India has strong and sustainable trade intensity with Bhutan. There is seen a great variation in intensity rate i.e. ups and downs. The rate of intensity was highest in 1996 i.e. 382.3565 thereafter a great fall in its rate i.e. 92.3914 in 1997. India's import intensity always remains greater than export intensity that means India's imports from Bhutan are greater than its exports to. India's exports to and imports from Bhutan frequently increased and decreased. In 1994, gap between import with export intensity was maximum i.e. 526.9876. Overall, India has trade prospects with Bhutan. 


\section{Discussion and Conclusions}

India has become Bhutan's largest trading partner. Trade between them continued to increase. India has full trade potential and prospects with Bhutan due to high rate of intensity. No doubt, trend shows too much ups and downs. India's imports intensity is greater than export intensity during the entire period that means India's imports from Bhutan exceeds its exports to. India has no trade specialisation in the export of any product to Bhutan, but has import specialisation in the product with code 74 since 2003. Except 74, India can also import product with 20 and 72 from Bhutan. India's trade with Bhutan went to increase year after year. Still India should make efforts to develop trade specialisation in products that will lead to enhance the level of integration.

\section{Acknowledgements}

Author is thankful to University Grants Commission for providing financial assistance in the form of Senior Research Fellowship to her.

\section{References:}

[1] Balasaa, B. (1965). Trade Liberalisation and Revealed Comparative Advantage, The Manchester School of Economics and Social Studies, Vol. 33, pp. 99-123.

[2] Bhagwati, J. (1993). Regionalism and Multilateralism: An Overview, In New Dimensions in Regional Integration, Cambridge, ed. by de Melo J. and Panagariya, A. University Press, Cambridge.

[3] Devi, T.N. (1989). Regional Economic Co-operation in South Asia, Chugh Publications, Allahabad.

[4] Drysadale P.D. and Garnaut, R. (1982), Trade Intensities and the Analysis of Bilateral Trade Flows in a Many-Country World: A Survey, HhabwhathilaNr//a/fEcolo/thf, Vol. 22, No. 2, pp. 62-84.

[5] Ethier, W.J. (1998). The New Regionalism. The Economic Journal, Vol. 108, No. 449, pp. 1149-1161.

[6] Krugman, P. (1993). Regionalism versus Multilateralism: Analytical Notes, In New Dimensions in Regional Integration, ed. by Melo J. and Panagariya, A., CUP, Cambrdige.

[7] Malik, A.H. and Sheikh, N.A. (2016). Changing Dynamics of Indo-Bhutan Relations: Implications for India, International Journal of Social Science and Development, Vol.4, No. 2, pp. 44-53. 
Table-1 India's Engagement in RTAs

\begin{tabular}{|l|l|}
\hline \multicolumn{1}{|c|}{ Engagement in RTAs } & \multicolumn{1}{c|}{ Under Negotiation } \\
\hline $\begin{array}{l}\text { Association of South East Nations (ASEAN) - } \\
\text { India Free Trade Agreement (AIFTA) }\end{array}$ & $\begin{array}{l}\text { India-Mauritius Comprehensive Economic } \\
\text { Cooperation and Partnership Agreement (CEPA) }\end{array}$ \\
\hline $\begin{array}{l}\text { South Asia Association for Regional Cooperation } \\
\text { (SAARC) }\end{array}$ & $\begin{array}{l}\text { India-South African Customs Union (SACU) } \\
\text { Preferential Trade Agreement }\end{array}$ \\
\hline $\begin{array}{l}\text { South Asia Preferential Trade Agreement } \\
\text { SAPTA) }\end{array}$ & India-Pakistan Trading Agreement \\
\hline South Asia Free Trade Agreement (SAFTA) & India-EU FTA \\
\hline Asia Pacific Trade Agreement (APTA) & India-EFTA \\
\hline India-MERCOSUR & India-New Zealand \\
\hline India-Sri Lanka & India-Canada \\
\hline $\begin{array}{l}\text { India-Thailand Comprehensive Economic } \\
\text { Cooperation Agreement (IT-CECA) }\end{array}$ & $\begin{array}{l}\text { Bay of Bengal Initiative for Multi Sectoral } \\
\text { Technical Economic Cooperation-FTA }\end{array}$ \\
\hline India-Nepal & $\begin{array}{l}\text { Brazil, India, Russia, China and South Africa } \\
\text { (BRICS) }\end{array}$ \\
\hline India-Singapore & India-Gulf Cooperation Council (GCC) FTA \\
\hline India-Chile & India-Australia \\
\hline India-Afghanistan & India-Indonesia \\
\hline India-Bhutan & India-Israel \\
\hline India-Japan & India-Finland \\
\hline India-Korea, Republic of & India-Africa Trade Agreement \\
\hline India-Malaysia & India-Egypt \\
\hline India-Maldives & \\
\hline GSTP & \\
\hline
\end{tabular}

Source: Government of India, Ministry of Commerce and Industry

Table-2 Key Indicators of India and Bhutan Economy

\begin{tabular}{|l|c|c|}
\hline Indicators & India & Bhutan \\
\hline GDP (US\$ Current) 2015 & 2073542978200 & 1962221695.70 \\
\hline GDP growth (\%) 2015 & 7.57 & 3.25 \\
\hline Area & 3287260 & 38394 \\
\hline Population & 1267401849 & 765552 \\
\hline Population growth (\% per annual) & 426 & 2 \\
\hline Population density (people per square of land area) & 5760 & 20 \\
\hline $\begin{array}{l}\text { GNI per capita, Purchasing Power Purity (PPP) (current } \\
\text { international) }\end{array}$ & & 7560 \\
\hline GNI per capita (Atlas Method Current US\$) 2015 & 2049502018400 & 1847612463.50 \\
\hline Agriculture, value added (\% of GDP) & 17 & 17 \\
\hline Industry, value added (\% of GDP) & 30 & 42 \\
\hline Service, etc (\% of GDP) & 53 & 41 \\
\hline Exports of goods and services (\%age of GDP) & 24 & 39 \\
\hline Imports of goods and services (\%age of GDP) & 26 & 67 \\
\hline Foreign Direct Investment (FDI) (US\$) & 34410758384 & 8379987 \\
\hline Gross Domestic Capital Formation (\%age of GDP) & 31 & 46 \\
\hline Human Development Index (HDI) Rank & 135 & 136 \\
\hline
\end{tabular}

\section{Source: World Integrated Trade Solution (wits)}


Table-3 Bilateral Trade between India and Bhutan (US\$ thousand)

\begin{tabular}{|c|c|c|c|c|}
\hline Year & $\begin{array}{c}\text { Export from } \\
\text { India to Bhutan }\end{array}$ & $\begin{array}{c}\text { Import of India } \\
\text { from Bhutan }\end{array}$ & $\begin{array}{c}\text { Export from } \\
\text { Bhutan to India }\end{array}$ & $\begin{array}{c}\text { Import of Bhutan } \\
\text { from India }\end{array}$ \\
\hline 1990 & $2,154.84$ & 798.02 & NA & NA \\
\hline 1991 & $1,197.49$ & 496.5 & NA & NA \\
\hline 1992 & $2,423.72$ & $1,354.52$ & NA & NA \\
\hline 1993 & $9,935.2$ & $2,980.28$ & $59,054.02$ & $3,330.98$ \\
\hline 1994 & $11,092.2$ & $18,281.72$ & $62,015.07$ & $3,483.54$ \\
\hline 1995 & $17,136.13$ & $34,665.42$ & NA & NA \\
\hline 1996 & $21,979.93$ & $33,766.85$ & NA & NA \\
\hline 1997 & $13,329.52$ & $13,421.32$ & NA & NA \\
\hline 1998 & $9,556.5$ & $6,132.82$ & $1,01,637.7$ & $4,422.02$ \\
\hline 1999 & $7,618.64$ & $18,111.85$ & $1,09,509.1$ & $5,305.15$ \\
\hline 2000 & 1,087 & $18,330.76$ & NA & NA \\
\hline 2001 & $5,965.03$ & $23,314.04$ & NA & NA \\
\hline 2002 & $23,119.47$ & $24,855.69$ & NA & NA \\
\hline 2003 & $84,919.38$ & $52,813.14$ & NA & NA \\
\hline 2004 & $87,008.3$ & $50,910.46$ & NA & NA \\
\hline 2005 & $95,127.99$ & $1,00,065.7$ & $2,26,229.4$ & $2,90,684.7$ \\
\hline 2006 & $63,804.76$ & $1,16,287.4$ & $3,19,432.4$ & $2,87,629.6$ \\
\hline 2007 & $70,837.99$ & $2,02,117.4$ & $5,50,186.8$ & $3,65,393.7$ \\
\hline 2008 & $1,06,121.7$ & $1,59,772.9$ & $4,95,781.2$ & $4,01,750.6$ \\
\hline 2009 & $1,08,475.6$ & $1,40,890.2$ & $4,63,640.4$ & $4,12,106.6$ \\
\hline 2010 & $1,59,214.6$ & $1,85,690.3$ & $3,40,823.8$ & $6,40,817.5$ \\
\hline 2011 & $2,19,077$ & $2,05,678.3$ & $3,43,018.4$ & $7,60,194$ \\
\hline 2012 & $1,70,757.6$ & $1,69,271.8$ & $4,97,716.6$ & $7,81,471.3$ \\
\hline 2013 & $1,61,666.9$ & $1,37,064.2$ & NA & NA \\
\hline 2014 & $2,00,366$ & $1,44,346$ & NA & NA \\
\hline Source & $01 d 1969$ & & \\
\hline
\end{tabular}

Source: World Integrated Trade Solution (wits) 


\section{Annexure-1 Product Codes-2 digit SITC, Revision 2}

\begin{tabular}{|c|c|c|c|}
\hline $\begin{array}{l}\text { Product } \\
\text { Code }\end{array}$ & Product Description & $\begin{array}{l}\text { Product } \\
\text { Code }\end{array}$ & Product Description \\
\hline 1 & Live animals & 51 & Wool, animal hair, horsehair yarn and fabric thereof \\
\hline 2 & Meat and edible meat offal & 52 & Cotton \\
\hline 3 & Fish, crustaceans, molluscs, aquatic invertebrates nes & 53 & Vegetable textile fibres nes, paper yarn, woven fabric \\
\hline 4 & Dairy products, eggs, honey, edible animal product nes & 54 & Manmade filaments \\
\hline 5 & Products of animal origin & 55 & Manmade staple fibres \\
\hline 6 & Live trees, plants, bulbs, roots, cut flowers etc & 56 & Wadding, felt, nonwovens, yarn, twine, cordage, etc \\
\hline 7 & Edible vegetables and certain roots and tubers & 57 & Carpets and other textile floor coverings \\
\hline 8 & Edible fruit, nuts, peel of citrus fruit, melons & 58 & Special woven or tufted fabric, lace, tapestry etc \\
\hline 9 & Coffee, tea mate and spices & 59 & Impregnated, coated or laminated textile fabric \\
\hline 10 & Cereals & 60 & Knitted or crocheted fabric \\
\hline 11 & Milling products, malt, starches, inulin, wheat gluten & 61 & Articles of apparel, accessories, knit or crochet \\
\hline 12 & Oil seed, oleagic fruit, grain, seed, fruit, etc, nes & 62 & Articles of apparel, accessories, not knit or crochet \\
\hline 13 & Lac, gums, resins, vegetable saps and extracts nes & 63 & Other made textiles articles, sets, worn clothing etc \\
\hline 14 & Vegetable plaiting materials, vegetable products nes & 64 & Footwear, gaiters and the like, parts thereof \\
\hline 15 & Animal, vegetable fats and oils, cleavage products, etc & 65 & Headgear and parts thereof \\
\hline 16 & Meat, fish and seafood food preparations nes & 66 & Umbrellas, walking-sticks, seat-sticks, whips, etc \\
\hline 17 & Sugars and sugar confectionery & 67 & Bird skin, feathers, artificial flowers, human hair \\
\hline 18 & Cocoa and cocoa preparations & 68 & Stone, plaster, cement, asbestos, mica, etc articles \\
\hline 19 & Cereal, flour, starch, milk preparations and products & 69 & Ceramic products \\
\hline 20 & Vegetable, fruit, nut, etc food preparations & 70 & Glass and glassware \\
\hline 21 & Miscellaneous edible preparations & 71 & Pearls, precious stones, metals, coins, etc \\
\hline 22 & Beverages, spirits and vinegar & 72 & Iron and steel \\
\hline 23 & Residues, wastes of food industry, animal fodder & 73 & Articles of iron or steel \\
\hline 24 & Tobacco and manufactured tobacco substitutes & 74 & Copper and articles thereof \\
\hline 25 & Salt, sulphur, earth, stone, plaster, lime and cement & 75 & Nickel and articles thereof \\
\hline 26 & Ores, slag and ash & 76 & Aluminum and articles thereof \\
\hline 27 & Mineral fuels, oils, distillation products, etc & 78 & Lead and articles thereof \\
\hline 28 & Inorganic chemicals, precious metal compound, isotopes & 79 & Zinc and articles thereof \\
\hline 29 & Organic chemicals & 80 & Tin and articles thereof \\
\hline 30 & Pharmaceutical products & 81 & Other base metals, cermets, articles thereof \\
\hline 31 & Fertilizers & 82 & Tools, implements, cutlery, etc of base metal \\
\hline
\end{tabular}

Full Text DOI: http://dx.doi.org/10.21013/jmss.v5.n3.p7 


\begin{tabular}{|l|l|l|l|}
\hline 32 & Tanning, dyeing extracts, tannins, derivs, pigments etc & 83 & Miscellaneous articles of base metal \\
\hline 33 & Essential oils, perfumes, cosmetics, toiletries & 84 & Machinery, nuclear reactors, boilers, etc \\
\hline 34 & Soaps, lubricants, waxes, candles, modeling pastes & 85 & Electrical, electronic equipment \\
\hline 35 & Albuminoids, modified starches, glues, enzymes & 86 & Railway, tramway locomotives, rolling stock, equipment \\
\hline 36 & Explosives, pyrotechnics, matches, pyrophorics, etc & 87 & Vehicles other than railway, tramway \\
\hline 37 & Photographic or cinematographic goods & 88 & Aircraft, spacecraft and parts thereof \\
\hline 38 & Miscellaneous chemical products & 89 & Ships, boats and other floating structures \\
\hline 39 & Plastic and articles thereof & 90 & Optical, photo, technical, medical, etc apparatus \\
\hline 40 & Rubber and articles thereof & 91 & Clock and watches and parts thereof \\
\hline 41 & Raw hides and skins (other than furskins) and leather & 92 & Musical instruments, parts and accessories \\
\hline 42 & Articles of leather, animal, gut, harness, travel goods & 93 & Arms and ammunition, parts and accessories thereof \\
\hline 43 & Furskins and artificial fur, manufactures thereof & 94 & Furniture, lighting, signs, prefabricated buildings \\
\hline 44 & Wood and articles of wood, wood charcoal & 95 & Toys, games, sports requisites \\
\hline 45 & Cork and articles of cork & 96 & Miscellaneous manufactured articles \\
\hline 46 & Manufactures of plaiting material, basketwork etc & 97 & Works of art, collectors pieces and antiques \\
\hline 47 & Pulp of wood, fibrous cellulosic material, waste etc & 99 & Commodities not elsewhere specified \\
\hline 48 & Paper and paperboard, articles of pulp, paper and board & & \\
\hline 49 & Printed books, newspapers, pictures etc & & \\
\hline 50 & Silk & & \\
\hline
\end{tabular}

Source: International Trade Centre, Geneva (ITC) 


\section{Annexure-2 India RCA for Exports to Bhutan (2001-2014)}

\begin{tabular}{|c|c|c|c|c|c|c|c|c|c|c|c|c|c|c|}
\hline Product Code & Bhutan & Bhutan & Bhutan & Bhutan & Bhutan & Bhutan & Bhutan & Bhutan & Bhutan & Bhutan & Bhutan & Bhutan & Bhutan & Bhutan \\
\hline 1 & 0 & 0 & 0 & 0 & 0 & 0 & 0 & 0 & 0.07 & 0 & 0 & 0.01 & 0.01 & 0.02 \\
\hline 2 & 0 & 0 & 0 & 0 & 0 & 0 & 0 & 0.005 & 0.007 & 0.01 & 0.009 & 0.005 & 0.004 & 0.003 \\
\hline 3 & 0 & 0 & 0.0002 & 0.005 & 0.001 & 0.001 & 0 & 0 & 0.0004 & 0.002 & 0.0001 & 0.0003 & 0.0001 & 0.00004 \\
\hline 5 & 0 & 0 & 0 & 0 & 0 & 0 & 0 & 0.06 & 0 & 0 & 0 & 0 & 0 & 0 \\
\hline 6 & 0 & 0 & 0 & 0.01 & 0 & 0.0001 & 0 & 0 & 0.007 & 0.007 & 0 & 0.0005 & 0 & 0.01 \\
\hline 7 & 0.001 & 0 & 0.03 & 0.02 & 0.0005 & 0 & 0 & 0 & 0.0006 & 0 & 0 & 0 & 0.0006 & 0.001 \\
\hline 8 & 0 & 0 & 0.0004 & 0.0002 & 0.00002 & 0.0001 & 0.001 & 0.0004 & 0.001 & 0.0003 & 0.001 & 0.0007 & 0.0004 & 0.002 \\
\hline 9 & 0.00006 & 0 & 0.0008 & 0.0001 & 0 & 0 & 0.0003 & 0.002 & 0.004 & 0.0008 & 0.001 & 0.0004 & 0.0008 & 0.0007 \\
\hline 10 & 0.03 & 0.03 & 0.06 & 0.05 & 0.04 & 0.03 & 0.01 & 0.006 & 0.009 & 0.007 & 0.008 & 0.004 & 0.003 & 0.004 \\
\hline 11 & 0 & 0.04 & 0.04 & 0.12 & 0.02 & 0.003 & 0.03 & 0.02 & 0.03 & 0.05 & 0.008 & 0.0007 & 0.0004 & 0.009 \\
\hline 12 & 0.0007 & 0 & 0 & 0 & 0 & 0 & 0.001 & 0.0004 & 0 & 0 & 0 & 0 & 0.0001 & 0.00004 \\
\hline 13 & 0 & 0 & 0 & 0 & 0 & 0.01 & 0 & 0 & 0 & 0 & 0.00008 & 0.0002 & 0 & 0.00007 \\
\hline 14 & 0 & 0 & 0 & 0.005 & 0 & 0 & 0 & 0 & 0 & 0 & 0 & 0 & 0 & 0 \\
\hline 15 & 0 & 0.004 & 0.08 & 0.07 & 0.05 & 0.02 & 0.03 & 0.04 & 0.000404 & 0 & 0 & 0 & 0 & 0.002 \\
\hline 16 & 0 & 0 & 0 & 0 & 0 & 0 & 0 & 0 & 0 & 0 & 0 & 0 & 0 & 0 \\
\hline 18 & 0 & 0 & 0.03 & 0.71 & 0.64 & 0 & 0 & 0 & 0.01 & 0.008 & 0.07 & 0.053 & 0.64 & 0.12 \\
\hline 19 & 0.01 & 0.02 & 0.13 & 0.65 & 0.17 & 0.08 & 0.06 & 0.06 & 0.25 & 0.08 & 0.20 & 0.031 & 0.18 & 0.49 \\
\hline 20 & 0 & 0 & 0.004 & 0.06 & 0.01 & 0.01 & 0.01 & 0.02 & 0.03 & 0.02 & 0.03 & 0.02 & 0.007 & 0.009 \\
\hline 21 & 0.02 & 0.02 & 0.04 & 0.11 & 0.07 & 0.06 & 0.009 & 0.01 & 0.01 & 0.01 & 0.007 & 0.004 & 0.03 & 0.007 \\
\hline 22 & 0.63 & 1.2 & 1.61 & 1.79 & 0.87 & 0.34 & 0.19 & 0.08 & 0.34 & 0.17 & 0.20 & 0.11 & 0.01 & 0.02 \\
\hline 23 & 0 & 0 & 0.0002 & 0.002 & 0.004 & 0 & 0.0005 & 0.002 & 0.0003 & 0.0001 & 0.0004 & 0.001 & 0.0001 & 0.0001 \\
\hline 24 & 0 & 0 & 0 & 0 & 0 & 0 & 0 & 0.00002 & 0 & 0 & 0 & 0 & 0 & 0 \\
\hline 25 & 0.0003 & 0.001 & 0.07 & 0.04 & 0.04 & 0.01 & 0.02 & 0.01 & 0.05 & 0.02 & 0.12 & 0.10 & 0.09 & 0.06 \\
\hline 26 & 0 & 0 & 0 & 0.002 & 0.000009 & 0 & 0.003 & 0.01 & 0.007 & 0.03 & 0.01 & 0.004 & 0.00009 & 0.005 \\
\hline 27 & 0.003 & 0.01 & 0.01 & 0.01 & 0.01 & 0.01 & 0.009 & 0.01 & 0.03 & 0.01 & 0.02 & 0.01 & 0.02 & 0.02 \\
\hline 28 & 0.007 & 0.005 & 0.01 & 0.009 & 0.006 & 0.006 & 0.002 & 0.004 & 0.009 & 0.006 & 0.01 & 0.005 & 0.003 & 0.002 \\
\hline 29 & 0.0004 & 0.004 & 0.004 & 0.002 & 0.001 & 0.0009 & 0.0007 & 0.003 & 0.001 & 0.001 & 0.003 & 0.0005 & 0.0005 & 0.0004 \\
\hline 30 & 0.0006 & 0.0002 & 0.001 & 0.004 & 0.003 & 0.002 & 0.008 & 0.006 & 0.004 & 0.001 & 0.0008 & 0.002 & 0.001 & 0.0008 \\
\hline 31 & 0 & 0 & 0.01 & 0.04 & 0.01 & 0 & 0.002 & 0 & 0.007 & 0.007 & 0.008 & 0.01 & 0.002 & 0 \\
\hline 32 & 0 & 0 & 0.001 & 0.004 & 0.005 & 0.003 & 0.001 & 0.003 & 0.002 & 0.0006 & 0.001 & 0.002 & 0.001 & 0.001 \\
\hline 33 & 0 & 0 & 0.02 & 0.008 & 0.02 & 0.01 & 0.005 & 0.002 & 0.0005 & 0.0001 & 0.003 & 0 & 0.005 & 0.008 \\
\hline
\end{tabular}




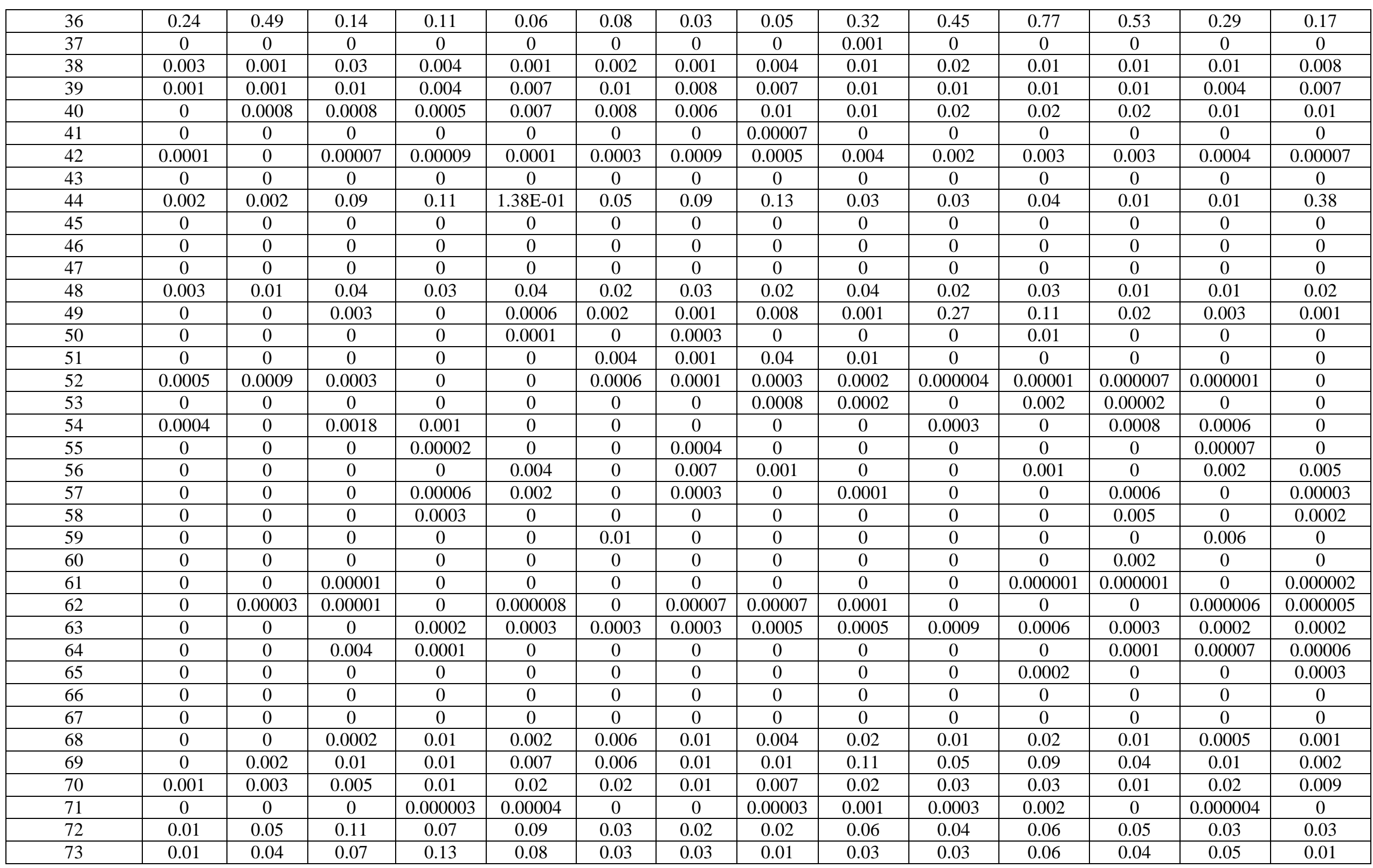




\begin{tabular}{|c|c|c|c|c|c|c|c|c|c|c|c|c|c|c|}
\hline 74 & 0 & 0 & 0.002 & 0.002 & 0.006 & 0 & 0 & 0.002 & 0.003 & 0.0006 & 0.0003 & 0.001 & 0.0001 & 0.0001 \\
\hline 75 & 0 & 0 & 0 & 0 & 0 & 0 & 0 & 0 & 0 & 0 & 0 & 0 & 0 & 0 \\
\hline 76 & 0.007 & 0.001 & 0.01 & 0.007 & 0.004 & 0.005 & 0.009 & 0.002 & 0.0004 & 0.002 & 0.002 & 0 & 0.005 & 0.006 \\
\hline 78 & 0 & 0 & 0 & 0 & 0 & 0 & 0 & 0.005 & 0.06 & 0 & 0 & 0 & 0.001 & 0 \\
\hline 80 & 0 & 0.03 & 0 & 0.01 & 0.01 & 0.56 & 0.71 & 0.09 & 0 & 0.008 & 0.12 & 0 & 0.0005 & 0 \\
\hline 81 & 0 & 0 & 0 & 0.15 & 0 & 0 & 0 & 0 & 0 & 0 & 0 & 0 & 0 & 0 \\
\hline 82 & 0 & 0 & 0.06 & 0.004 & 0.05 & 0.009 & 0.004 & 0 & 0.002 & 0.004 & 0.008 & 0.007 & 0.0001 & 0.003 \\
\hline 83 & 0.0006 & 0.02 & 0.006 & 0.04 & 0.03 & 0.01 & 0.02 & 0.002 & 0.01 & 0.02 & 0.06 & 0.02 & 0.02 & 0.01 \\
\hline 84 & 0.003 & 0.01 & 0.09 & 0.05 & 0.04 & 0.04 & 0.02 & 0.02 & 0.03 & 0.05 & 0.04 & 0.03 & 0.01 & 0.006 \\
\hline 85 & 0.007 & 0.05 & 0.21 & 0.12 & 0.14 & 0.04 & 0.04 & 0.03 & 0.02 & 0.03 & 0.03 & 0.03 & 0.008 & 0.009 \\
\hline 86 & 0 & 0.18 & 0 & 0 & 0.52 & 0 & 0 & 0.008 & 0 & 0.002 & 0 & 0.01 & 0 & 0.03 \\
\hline 87 & 0.01 & 0.10 & 0.08 & 0.09 & 0.05 & 0.04 & 0.06 & 0.07 & 0.13 & 0.11 & 0.17 & 0.04 & 0.004 & 0.005 \\
\hline 88 & 0 & 0 & 0 & 0 & 0 & 0 & 0.0004 & 0 & 0 & 0 & 0.05 & 0.00009 & 0.00002 & 0.00002 \\
\hline 89 & 0 & 0 & 0 & 0 & 0 & 0 & 0 & 0 & 0 & 0 & 0 & 0 & 0.00003 & 0 \\
\hline 90 & 0 & 0.002 & 0.03 & 0.01 & 0.01 & 0.03 & 0.006 & 0.03 & 0.03 & 0.007 & 0.01 & 0.007 & 0.008 & 0.003 \\
\hline 91 & 0 & 0 & 0.0006 & 0 & 0 & 0 & 0 & 0.0009 & 0 & 0.003 & 0 & 0.001 & 0.003 & 0.007 \\
\hline 93 & 0 & 0 & 0.14 & 0 & 0 & 0 & 0.07 & 0 & 0 & 0.25 & 0 & 0 & 0 & 0 \\
\hline 94 & 0 & 0.30 & 0.03 & 0.006 & 0.006 & 0.01 & 0.0008 & 0.004 & 0.01 & 0.01 & 0.02 & 0.006 & 0.003 & 0.007 \\
\hline 95 & 0 & 0 & 0 & 0.001 & 0 & 0.0001 & 0 & 0 & 0 & 0 & 0 & 0 & 0 & 0.001 \\
\hline 96 & 0 & 0 & 0 & 0 & 0 & 0.002 & 0 & 0 & 0 & 0.01 & 0.01 & 0.03 & 0.01 & 0.005 \\
\hline 97 & 0 & 0 & 0.001 & 0.1 & 0.0008 & 0.0002 & 0.0003 & 0.001 & 0 & 0.004 & 0 & 0 & 0 & 0.001 \\
\hline 99 & 0.005 & 0.02 & 0.12 & 0.06 & 0.05 & 0.004 & 0.006 & 0.009 & 0.002 & 0.004 & 0.001 & 0.02 & 0.08 & 0.52 \\
\hline
\end{tabular}


Annexure-3 India RCA for Imports from Bhutan (2001-2014)

\begin{tabular}{|c|c|c|c|c|c|c|c|c|c|c|c|c|c|c|}
\hline Product Code & Bhutan & Bhutan & Bhutan & Bhutan & Bhutan & Bhutan & Bhutan & Bhutan & Bhutan & Bhutan & Bhutan & Bhutan & Bhutan & Bhutan \\
\hline 1 & 0 & 0 & 0 & 0 & 0 & 0 & 0 & 0 & 0 & 0 & 0 & 0 & 0 & 0 \\
\hline 2 & 0 & 0 & 0 & 0 & 0 & 0 & 0 & 0 & 0 & 0 & 0 & 0 & 0 & 0 \\
\hline 3 & 0 & 0 & 0 & 0 & 0 & 0 & 0 & 0 & 0 & 0 & 0 & 0 & 0 & 0 \\
\hline 5 & 0 & 0 & 0 & 0 & 0 & 0 & 0 & 0 & 0 & 0 & 0 & 0 & 0 & 0 \\
\hline 6 & 0 & 0 & 0 & 0 & 0 & 0 & 0 & 0 & 0 & 0 & 0 & 0 & 0 & 0 \\
\hline 7 & 0 & 0.003 & 0.08 & 0.08 & 0.07 & 0 & 0.001 & 0 & 0 & 0 & 0.0002 & 0 & 0 & 0 \\
\hline 8 & 0 & 0 & 0.10 & 0 & 0 & 0 & 0 & 0.004 & 0 & 0 & 0 & 0 & 0 & 0 \\
\hline 9 & 0.14 & 0.17 & 0.10 & 0.05 & 0.01 & 0.01 & 0 & 0 & 0 & 0 & 0 & 0 & 0.01 & 0.09 \\
\hline 10 & 0 & 0 & 0 & 0 & 0.01 & 0 & 0 & 0 & 0 & 0 & 0 & 0 & 0 & 0 \\
\hline 11 & 0 & 0 & 1.37 & 2.42 & 0.54 & 0.04 & 0 & 0 & 0 & 0 & 0 & 0.06 & 0 & 0 \\
\hline 12 & 0 & 0 & 0 & 0 & 0 & 0 & 0 & 0 & 0 & 0 & 0 & 0 & 0 & 0 \\
\hline 13 & 0 & 0 & 0 & 0 & 0 & 0 & 0 & 0 & 0 & 0 & 0 & 0 & 0 & 0 \\
\hline 14 & 0 & 0 & 0 & 0 & 0 & 0 & 0 & 0 & 0 & 0 & 0 & 0 & 0 & 0 \\
\hline 15 & 0 & 0 & 0 & 0 & 0.13 & 0.66 & 1.25 & 0.37 & 0 & 0 & 0 & 0 & 0 & 0 \\
\hline 16 & 0 & 0 & 0 & 0 & 0 & 0 & 0 & 0 & 0 & 0 & 0 & 0 & 0 & 0 \\
\hline 18 & 0 & 0 & 0 & 0 & 0 & 0 & 0 & 0 & 0 & 0 & 0 & 0 & 0 & 0 \\
\hline 19 & 0.006 & 0 & 0.003 & 0 & 0 & 0 & 0 & 0 & 0 & 0 & 0 & 0 & 0 & 0 \\
\hline 20 & 0.48 & 0.47 & 1.60 & 0.59 & 0.50 & 1.16 & 0.9 & 0.40 & 0.26 & 0.19 & 0.14 & 0.10 & 0.20 & 1.43 \\
\hline 21 & 0.07 & 0 & 0 & 0 & 0 & 0.05 & 0 & 0 & 0 & 0 & 0 & 0 & 0.07 & 0.01 \\
\hline 22 & 0.37 & 0.03 & 15.55 & 3.98 & 2.21 & 1.57 & 1.73 & 0.41 & 1.18 & 0.54 & 0.38 & 0.18 & 0.95 & 0.98 \\
\hline 23 & 0 & 0 & 0.001 & 0 & 0 & 0.004 & 0.03 & 0 & 0 & 0 & 0 & 0 & 0 & 0 \\
\hline 24 & 0 & 0 & 0 & 0 & 0 & 0 & 0 & 0 & 0 & 0 & 0 & 0 & 0 & 0 \\
\hline 25 & 0.06 & 0.14 & 0.10 & 0.05 & 0.08 & 0.07 & 0.38 & 0.08 & 0.09 & 0.07 & 0.08 & 0.02 & 0.03 & 0.44 \\
\hline 26 & 0 & 0 & 0 & 0 & 0 & 0 & 0 & 0 & 0 & 0 & 0.001 & 0 & 0 & 0 \\
\hline 27 & 0.0003 & 0.003 & 0.0007 & 0 & 0 & 0 & 0 & 0.00002 & 0 & 0.00001 & 0.00001 & 0.00008 & 0.0005 & 0.001 \\
\hline 28 & 0.83 & 1.46 & 1.72 & 0.76 & 0.72 & 0.56 & 0.80 & 1.12 & 1.05 & 0.91 & 0.84 & 0.88 & 1.01 & 1.05 \\
\hline 29 & 0 & 0 & 0 & 0 & 0 & 0 & 0 & 0 & 0 & 0 & 0 & 0 & 0 & 0 \\
\hline 30 & 0 & 0 & 0 & 0 & 0 & 0 & 0 & 0 & 0 & 0 & 0 & 0 & 0 & 0 \\
\hline 31 & 0 & 0 & 0 & 0 & 0 & 0 & 0 & 0 & 0 & 0 & 0 & 0 & 0 & 0 \\
\hline 32 & 0 & 0 & 0 & 0 & 0 & 0 & 0 & 0 & 0 & 0 & 0.0002 & 0 & 0 & 0 \\
\hline 33 & 0.007 & 0 & 0 & 0 & 0 & 0 & 0 & 0 & 0.002 & 0 & 0 & 0.00087 & 0.0009 & 0.03 \\
\hline
\end{tabular}




\begin{tabular}{|c|c|c|c|c|c|c|c|c|c|c|c|c|c|c|}
\hline 36 & 0 & 0 & 0 & 0 & 0 & 0 & 0 & 0 & 0 & 0 & 0 & 0 & 0 & 0 \\
\hline 37 & 0 & 0 & 0.14 & 0.73 & 1.10 & 0.59 & 1.32 & 3.91 & 0 & 0 & 0 & 0 & 0 & 0 \\
\hline 38 & 0 & 0 & 0.001 & 0.002 & 0 & 0 & 0 & 0.005 & 0.004 & 0.004 & 0.0003 & 0.03 & & 0 \\
\hline 39 & 0.01 & 0.01 & 0.05 & 0.009 & 0.002 & 0.008 & 0.01 & 0.06 & 0.08 & 0.13 & 0.10 & 0.06 & 0.09 & 0.09 \\
\hline 41 & 0 & 0 & 0 & 0 & 0 & 0 & 0 & 0 & 0 & 0 & 0 & 0 & 0 & 0 \\
\hline 42 & 0 & 0 & 0 & 0 & 0 & 0 & 0 & 0 & 0 & 0 & 0 & 0 & 0 & 0 \\
\hline 43 & 0 & 0 & 0 & 0 & 0 & 0 & 0 & 0 & 0 & 0 & 0 & 0 & 0 & 0 \\
\hline 44 & 0.66 & 0.75 & 1.11 & 0.59 & 0.66 & 0.65 & 0.63 & 0.57 & 0.78 & 0.44 & 0.38 & 0.45 & 0.24 & 0.24 \\
\hline 45 & 0 & 0 & 0 & 0 & 0 & 0 & 0 & 0 & 0 & 0 & 0 & 0 & 0 & 0 \\
\hline 46 & 0 & 0 & 0 & 0 & 0 & 0 & 0 & 0 & 0 & 0 & 0 & 0 & 0 & 0 \\
\hline 47 & 0 & 0 & 0 & 0 & 0 & 0 & 0 & 0 & 0 & 0 & 0 & 0 & 0 & 0 \\
\hline 48 & 0 & 0 & 0.0004 & 0 & 0.08 & 0.001 & 0 & 0 & 0 & 0.04 & 0 & 0 & 0 & 0 \\
\hline 49 & 0 & 0 & 0.01 & 0 & 0 & 0 & 0 & 0 & 0 & 0 & 0 & 0 & 0 & 0 \\
\hline 50 & 0 & 0 & 0 & 0 & 0 & 0 & 0 & 0 & 0 & 0 & 0 & 0 & 0 & 0 \\
\hline 51 & 0 & 0 & 0 & 0 & 0 & 0 & 0 & 0 & 0 & 0 & 0 & 0 & 0 & 0 \\
\hline 52 & 0 & 0 & 0 & 0 & 0 & 0 & 0 & 0 & 0 & 0.00003 & 0 & 0 & 0 & 0 \\
\hline 54 & 0 & 0 & 0.39 & 0.75 & 1.54 & 0.74 & 0.64 & 0.31 & 0.15 & 0.03 & 0.007 & 0.01 & 0.002 & 0.0003 \\
\hline 55 & 0 & 0 & 0.0003 & 0 & 0 & 0 & 0 & 0 & 0 & 0 & 0 & 0 & 0 & 0 \\
\hline 56 & 0 & 0 & 0.54 & 0 & 0 & 0 & 0 & 0 & 0 & 0 & 0 & 0 & 0 & 0 \\
\hline 57 & 0 & 0 & 0 & 0 & 0 & 0 & 0 & 0 & 0 & 0 & 0 & 0 & 0 & 0 \\
\hline 58 & 0 & 0 & 0 & 0 & 0 & 0 & 0 & 0 & 0 & 0 & 0 & 0 & 0 & 0 \\
\hline 59 & 0 & 0 & 0 & 0 & 0 & 0 & 0 & 0 & 0 & 0 & 0 & 0 & 0 & 0 \\
\hline 60 & 0 & 0 & 0 & 0 & 0 & 0 & 0 & 0 & 0 & 0 & 0 & 0 & 0 & 0 \\
\hline 61 & 0 & 0 & 0 & 0 & 0 & 0 & 0 & 0 & 0 & 0 & 0 & 0 & 0 & 0 \\
\hline 62 & 0 & 0 & 0 & 0 & 0 & 0 & 0 & 0 & 0 & 0 & 0 & 0 & 0.001 & 0 \\
\hline 63 & 0 & 0 & 0 & 0 & 0 & 0 & 0 & 0 & 0 & 0 & 0.007 & 0 & 0 & 0 \\
\hline 64 & 0 & 0 & 0 & 0 & 0 & 0 & 0 & 0 & 0 & 0 & 0 & 0 & 0 & 0 \\
\hline 65 & 0 & 0 & 0 & 0 & 0 & 0 & 0 & 0 & 0 & 0 & 0 & 0 & 0 & 0 \\
\hline 66 & 0 & 0 & 0 & 0 & 0 & 0 & 0 & 0 & 0 & 0 & 0 & 0 & 0 & 0 \\
\hline 67 & 0 & 0 & 0 & 0 & 0 & 0 & 0 & 0 & 0 & 0 & 0 & 0 & 0 & 0 \\
\hline 68 & 0 & 0 & 0 & 0 & 0 & 0 & 0 & 0.78 & 0.88 & 0.08 & 0.08 & 0.21 & 0.42 & 0.53 \\
\hline 69 & 0 & 0 & 0 & 0 & 0 & 0 & 0 & 0 & 0 & 0 & 0 & 0 & 0 & 0 \\
\hline 72 & 0.65 & 0.74 & 0.99 & 0.61 & 0.50 & 0.48 & 0.59 & 0.96 & 1.61 & 1.71 & 1.68 & 1.57 & 1.73 & 1.14 \\
\hline 73 & 0.002 & 0 & 0.005 & 0 & 0 & 0.0001 & 0 & 0.0001 & 0 & 0 & 0 & 0 & 0 & 0 \\
\hline
\end{tabular}

Full Text DOI: http://dx.doi.org/10.21013/jmss.v5.n3.p7 


\begin{tabular}{|c|c|c|c|c|c|c|c|c|c|c|c|c|c|c|}
\hline 74 & 0 & 0 & 1.26 & 1.49 & 2.85 & 5.08 & 7.76 & 1.70 & 3.30 & 3.34 & 2.97 & 1.76 & 0.27 & 0.19 \\
\hline 75 & 0 & 0 & 0 & 0 & 0 & 0 & 0 & 0 & 0 & 0 & 0 & 0 & 0 & 0 \\
\hline 76 & 0 & 0 & 0 & 0 & 0 & 0 & 0 & 0 & 0 & 0 & 0 & 0 & 0 & 0 \\
\hline 78 & 0 & 0 & 0 & 0 & 0 & 0 & 0 & 0 & 0 & 0 & 0 & 0 & 0 & 0 \\
\hline 79 & 0 & 0 & 0 & 0 & 0 & 0 & 0 & 0 & 0 & 0 & 0 & 0 & 0 & 0 \\
\hline 80 & 0 & 0 & 0 & 0 & 0 & 0 & 0 & 0 & 0 & 0 & 0 & 0 & 0 & 0 \\
\hline 81 & 0 & 0 & 0 & 0 & 0 & 0 & 0 & 0 & 0 & 0 & 0 & 0 & 0 & 0 \\
\hline 82 & 0 & 0 & 0 & 0 & 0 & 0 & 0.003 & 0 & 0 & 0 & 0 & 0 & 0 & 0 \\
\hline 83 & 0 & 0 & 0 & 0 & 0 & 0 & 0 & 0 & 0 & 0 & 0 & 0 & 0 & 0 \\
\hline 84 & 0.006 & 0 & 0.0009 & 0.0001 & 0 & 0 & 0 & 0 & 0 & 0 & 0.00007 & 0 & 0 & 0 \\
\hline 85 & 0.0002 & 0 & 0.003 & 0 & 0 & 0 & 0.001 & 0.002 & 0.0005 & 0.00006 & 0.001 & 0.0003 & 0 & 0 \\
\hline 86 & 0 & 0 & 0 & 0 & 0 & 0 & 0 & 0 & 0 & 0 & 0 & 0 & 0 & 0 \\
\hline 87 & 0 & 0 & 0 & 0 & 0 & 0 & 0 & 0 & 0 & 0 & 0 & 0 & 0 & 0 \\
\hline 88 & 0 & 0 & 0 & 0 & 0 & 0 & 0 & 0 & 0 & 0 & 0 & 0 & 0 & 0 \\
\hline 89 & 0 & 0 & 0 & 0 & 0 & 0 & 0 & 0 & 0 & 0 & 0 & 0 & 0 & 0 \\
\hline 90 & 0.00008 & 0 & 0 & 0 & 0 & 0 & 0 & 0 & 0 & 0 & 0 & 0 & 0 & 0 \\
\hline 91 & 0 & 0 & 0 & 0 & 0 & 0 & 0 & 0 & 0 & 0 & 0 & 0 & 0 & 0 \\
\hline 93 & 0 & 0 & 0 & 0 & 0 & 0 & 0 & 0 & 0 & 0 & 0 & 0 & 0 & 0 \\
\hline 94 & 0 & 0 & 0 & 0 & 0.003 & 0.03 & 0.06 & 0.04 & 0.24 & 0.10 & 0.06 & 0.008 & 0 & 0 \\
\hline 95 & 0 & 0 & 0 & 0 & 0 & 0 & 0 & 0 & 0 & 0 & 0 & 0 & 0 & 0 \\
\hline 96 & 0 & 0 & 0 & 0.01 & 0 & 0 & 0 & 0 & 0 & 0 & 0 & 0 & 0 & 0 \\
\hline 97 & 0 & 0 & 0 & 0 & 0 & 0 & 0 & 0 & 0 & 0 & 0 & 0 & 0 & 0 \\
\hline 99 & 0.0001 & 0 & 0.13 & 0.15 & 0.12 & 0.07 & 0.01 & 0 & 0 & 0 & 0.0006 & 0.00001 & 0.0001 & 0 \\
\hline
\end{tabular}

